\title{
Correspondence
}

\section{Mild hypothermia therapy after cardiopulmonary resuscitation may improve cerebral resuscitation}

Mild hypothermia has attracted considerable attention to assist cerebral resuscitation after cardiopulmonary arrest. ${ }^{1}$ However, the definitive procedure has not been established. Our method involves cooling to a tympanic temperature of $33-34^{\circ} \mathrm{C}$ using systemic alcohol spray and blanket for several hours, and maintaining that temperature for fivc days, followed by spontaneous rewarming. Furthermore, $0.5 \mathrm{mg} \cdot \mathrm{kg}^{-1} \cdot \mathrm{hr}^{-1}$ midazolam continuously and mannitol $1 \mathrm{~g} \cdot \mathrm{kg}^{-1}$ iv rapidly every six hours are administered during this period. Using these procedures, we experienced four cases completely recovered from cardiopulmonary arrest.

Summary data of these patients are presented in the Table below. The Emergency Medical Team transported the patients to our emergency room, while perfoming ventilation by mask using oxygen and extemal cardiac massage. By advanced life support, case \#l was immediately recovered heart beat, but case \#3 needed a further $30 \mathrm{~min}$ before heart beat was restored. In case \#2, temporary cardiac pacing restored blood pressure two hours after arrival. All cases, subsequently, received mild hypothermia therapy. Consciouness returned eight days later in case \#1, 9 days later in case \#2,8 days later in case \#3 and 9 days later in case \#4.

Fom the present cases, it is difficult to evaluate the effectiveness of mild hypothermia on cerebral resuscitation. However, it has been suggested that mild hypothermia should be used morte for brain protection during neurosurgical anesthesia. ${ }^{2}$ Although the mechanism has not been elucidated, we consider that mild hypothermia therapy may improve cerebral resuscitation.

Hiroshi Iwama MD, Kazuhiro Watanabe MD

Katsunori Shiraishi MD, Takashi Suzuki MD

Jiro Shimada MD

Departmentof Anesthesiology

Fukushima Medical College

Fukushima, Japan

\section{REFERENCES}

1 Leonov $\Upsilon$, Sterz F, Safar $P$, et al. Mild cerebral hypothermia during and after cardiac arrest improves neurologic outcome in dogs. J Cereb Blood Flow Metab 1990; 10: 57-70.

2 Milde $L N$. Clinical use of mild hypothermia for brain protection: a dream revisited. J Neurosurg Anesthesiol 1992; 4: 211-5.

\section{Aging and cardiovascular autonomic regulation}

In a recent issue of the Journal, Nakayama et al. ${ }^{1}$ reported an asystolic cardiac arrest occurring during removal of a pulmonary balloon catheter. Immediately after the PA catheter was removed hypotension, bradycardia and asystole developed. The authors attributed this unexpected cardiac event to increased parasympathetic activity. They also remarked that this increased response would be expected with aging. It is a daily occurrence for clinicians to observe that, in

TABLE Summary of the patients

\begin{tabular}{|c|c|c|c|c|c|c|c|}
\hline No. & Age/Sex & Cause & $\begin{array}{l}\text { Estimated time } \\
\text { Until CPR }\end{array}$ & $\begin{array}{l}\text { Bystander } \\
\text { CPR }\end{array}$ & $\begin{array}{l}\text { Estimated time } \\
\text { for arriving at } E R\end{array}$ & $\begin{array}{l}\text { EKG on } \\
\text { arrival }\end{array}$ & $\begin{array}{l}\text { Other findings } \\
\text { on arrival }\end{array}$ \\
\hline Case 1 & $1 \mathrm{yr} / \mathrm{male}$ & Drowning in bath & About $10 \mathrm{~min}$ & - & About $40 \mathrm{~min}$ & Standstill & $\begin{array}{l}\text { Axillary } \\
\text { temperature } 37.6^{\circ} \mathrm{C}\end{array}$ \\
\hline Case 2 & $75 \mathrm{yr} /$ male & $\begin{array}{l}\text { Complete atrio- } \\
\text { ventricular block }\end{array}$ & Immediate & + & $22 \mathrm{~min}$ & Standstill & \\
\hline Case 3 & $75 \mathrm{yr} / \mathrm{male}$ & $\begin{array}{l}\text { Fall into the sea } \\
\text { with the car }\end{array}$ & $15 \mathrm{~min}$ & - & $30 \mathrm{~min}$ & Standstill & $\begin{array}{l}\text { Rectal } \\
\text { temperature } 33^{\circ} \mathrm{C}\end{array}$ \\
\hline Case 4 & $6 \mathrm{yr} / \mathrm{male}$ & $\begin{array}{l}\text { Drowning in } \\
\text { the warm pool }\end{array}$ & About $10 \mathrm{~min}$ & - & About $50 \mathrm{~min}$ & Sinus rhythm & $\begin{array}{l}\text { Gasping } \\
\text { Decerebration }\end{array}$ \\
\hline
\end{tabular}

$\mathrm{CPR}=$ Cardiopulmonary resuscitation. $\mathrm{ER}=$ Emergency room. 